\title{
POLSKA BIBLIOGRAFIA ANTYKU CHRZEŚCIJAŃSKIEGO 2002
}

\section{DZIAŁY TEMATYCZNE}

1. Prace zbiorowe (antologie tekstów i opracowania)

2. Bibliografie i problemy metodologiczne

3. Prace ogólne, historie literatury

4. Historia wspólnot, instytucji, okresów historycznych, regionów

5.1. Historia doktryn (teologia)

5.2. Historia doktryn (filozofia)

6. Liturgia

7. Hagiografia i historia duchowości

8. Archeologia i historia sztuki

9. Biblia

9.1. Apokryfy

9.2. Gnostycyzm

10. Patrystyka i średniowiecze (łacińskie i bizantyńskie)

11. Autorzy

12. Recenzje, omówienia

13. Sprawozdania

14. Wybrane publikacje z zakresu kultury klasycznej

\section{Prace zbiorowe (antologie tekstów i opracowania)}

Ad sapientiam cordis. Księga Pamiq̨tkowa dedykowana Księdzu Profesorowi Ludwikowi Gladyszewskiemu, red. P. Podeszwa - ks. W. Szczerbiński, Gniezno 2002.

Dokumenty Soborów Powszechnych, t. II (869-1313), tekst grecki, laciński i polski. Konstantynopol IV, Lateran I-IV, Lyon I-II, Vienne, oprac. A. Baron - H. Pietras, ŹMT 26, Kraków 2002, Wydawnictwo WAM.

Dziecko $w$ rodzinie $i$ społeczeństwie: starożytność - średniowiecze, red. J. Jundziłł - D. Żołądź-Strzelczyk, t. 1, Bydgoszcz 2002, Wydawnictwo Uczelniane Akademii Bydgoskiej. 
Encyklopedia Katolicka, t. IX (Kinszasa-Krzymuska), Lublin 2002 (także hasla patrystyczne).

Euergesias charin. Studies presented to Benedetto Bravo and Ewa Wipszycka by their disciples (The Journal of Iuristic Papyrology, Supplement I), ed. by T. Derda - J. Urbanik - M. Węcowski, Warszawa 2002.

Filokalia. Teksty o modlitwie serca, tłum. i oprac. Józef Naumowicz, wyd. II zmienione i rozszerzone, Kraków 2002, Wydawnictwo M.

Księga o Aniołach, red. Herbert Oleschko, Kraków 2002, Wydawnictwo WAM.

Ku prawdzie w mitości. Księga Pamiątkowa poświęcona Księdzu Biskupowi Profesorowi Janowi Śrutwie, red. S. Koczwara, Lublin 2002, Wydawnictwo KUL.

Sympozja Kazimierskie poświęcone kulturze świata późnego antyku i wczesnego chrześcijaństwa, t. 3, red. B. Iwaszkiewicz-Wronikowska-D. Próchniak, Lublin 2002, Wydawnictwo TN KUL. Prace Wydziału Historyczno-Filologicznego 87.

\section{Bibliografie i problemy metodologiczne}

DĘBSKI J., Pubblicazioni di Padre Raniero Cantalamessa OFMCap - predicatore della Casa Pontificia (anni 1960-1999), „Studia Laurentiana” 2 (2002) 137-163.

FIGIEL J., Patrystyka w czasopismach 2002 roku, VoxP 22 (2002) t. 42-43, 705739.

HRAB B., Bibliografia zawartości rocznika „Studia Gnesnensia” za lata 19752001, „Studia Gnesnensia” 16 (2002) 331-359 (patrologia: 334-335).

LONGOSZ S., Laikat w starożytności chrześcijańskiej. Materiały bibliograficzne, VoxP 22 (2002) t. 42-43, 631-637.

LONGOSZ S., Wykaz prac dyplomowych z antyku chrześcijańskiego ukończonych w niektórych polskich ośrodkach naukowych $w 2002$ roku, VoxP 22 (2002) t. 42-43, 695-704.

NAUMOWICZ J. - LONGOSZ S., Polska bibliografia antyku chrześcijańskiego 2002, VoxP 22 (2002) t. 42-43, 665-693.

NIEDŹWIECKI W., Didache - Nauka Dwunastu Apostołów. Bibliografia 1883-2000, VoxP 22 (2002) t. 42-43, 639-664.

OBRYCKI K., Św. Ambroży w pracach dyplomowych pisanych na polskich uczelniach katolickich w latach 1945-2000, CT 72 (2002) nr 4, 183-190.

PERADZE G., Pojęcie, zadania i metody patrologii $w$ teologii prawosławnej, „Cerkiewny Wiestnik” 2002, nr 4, 13-20.

STAROWIEYSKI M., Ks. prof. Józef Bilczewski - uczony, „Warszawskie Studia Teologiczne" 15 (2002) 141-156.

STAŚKIEWICZ S., Ksiądz Profesor Emil Stanula jako badacz antyku chrześcijańskiego, VoxP 22 (2002) t. 42-43, 525-535. 
WĄSOWICZ J., Elementy patrologii i historii starożytnego Kościoła w wybranych podręcznikach do szkót ponadpodstawowych, CT 72 (2002) nr 4, 179183.

WYGRALAK P., Hiszpańska historiografia kościelna „Anuario de Historia de la Iglesia” (1992-2001), „Poznańskie Studia Teologiczne” 13 (2002), 135-151.

\section{Prace ogólne, historie literatury}

GÓRNY J., Patrologia (literatura patrystyczna w zarysie), Olsztyn 2002, Wydział Duszpasterski Kurii Metropolitalnej Warmińskiej.

JUREWICZ O. (red.), Encyklopedia kultury bizantyńskiej, Warszawa 2002, Wydawnictwo Uniwersytetu Warszawskiego.

LONGOSZ S., Geneza i pierwsze znaczenie terminu „świecki” - „laicus" $w$ literaturze wczesnochrześcijańskiej, VoxP 22 (2002) t. 42-43, 53-65.

MIERZWA A., Historia historiografii, t. 1. Starożytność, średniowiecze, Toruń 2002, Wydawnictwo Adam Marszałek.

NARECKI K., Historia powstania stownika H.G. Liddella: A Greek-English Lexicon, „Meander” 57 (2002) 205-223.

NAUMOWICZ J., Chrześcijańska rachuba czasu. Refleksje na poczq̨tek III tysiaclecia, „Warszawskie Studia Teologiczne” 15 (2002) 133-140.

NIEŚCIOR L., Myśl wczesnochrześcijańska wobec wyzwania czasu. Wybrane zagadnienia z teologii Ojców (Biblioteka Pomocy Naukowych UAM, Wydzial Teologiczny 22), Poznań 2002.

REALE G., Historia filozofii starożytnej. t. 5, Stownik, indeksy $i$ bibliografia, wspótpraca R. Radice, tlum. E. Iwo Zieliński, Lublin 2002, Wydawnictwo KUL.

SCHATZ K., Sobory Powszechne. Punkty zwrotne w historii Kościota, thum. J. Zakrzewski, Kraków 2002, Wydawnictwo WAM.

SEMKOWICZ W., Paleografia tacińska, wyd. 2, Kraków 2002, Wydawnictwo Universitas.

STABRYŁA S., Historia literatury starożytnej Grecji i Rzymu. Zarys, Wrocław - Warszawa - Kraków 2002, Zakład Narodowy im. Ossolińskich (s. 217-263 i 456-483: Literatura chrześcijańska).

SWOBODA A., Rodzina w pismach Ojców Apostolskich, CT 72 (2002) nr 4, $37-48$;

SWOBODA A., Rodzina w pismach Ojców Apostolskich, „Poznańskie Studia Teologiczne" 13 (2002), 41-52.

SZMURŁO R., Krótki zarys historii języka i piśmiennictwa koptyjskiego, „Studia Teologiczne Białystok - Drohiczyn - Łomża” 20 (2002) 327-336.

\section{Historia wspólnot, instytucji, okresów historycznych, regionów}

BIRLEY A.R., Hadrian. Cesarz niestrudzony, tłum. R. Wiśniewski, Warszawa 2002, PIW. 
BRALEWSKI S., Uwagi na temat antyheretyckiego ustawodawstwa cesarza Konstantyna Wielkiego, „Przegląd Nauk Historycznych” 1 (2002) nr 1, 7-20. BRZOSTOWSKI Z.I., Józef Flawiusz „strażikiem prawa i sprawiedliwości”, „Przegląd Religioznawczy” 2002, nr 206, 3-8.

BULAS R., Bóg $i$ człowiek - wspóttwórcy świata. Kościót celtycki w Irlandii, „Miejsca Święte” 2002, nr 2, 12-17.

BURCZAK K., Biskupi afrykańscy wobec herezji pelagianizmu, VoxP 22 (2002) t. 42-43, 437-461.

CZEMBOR H., Dzieje chrześcijaństwa - starożytność, Cieszyn 2001.

CZERWIEŃ J., II Sobór Ekumeniczny. Próba rekonstrukcji przebiegu, w: Ku prawdzie $w$ milości [1], 17-32.

DATKO A., Krzyż $i$ jarzębina wiedzy, „Miejsca Święte” 2002, nr 2, 22-24.

DĘBIŃSKI A., Biskup $i$ życie gminy chrześcijańskiej $w$ mieście późnoantycznym, w: Sympozja Kazimierskie [zob. 1], 17-24.

DEGÓRSKI B., Wdowy w starożytności chrześcijańskiej i ich postuga w Kościele, VoxP 22 (2002) t. 42-43, 303-318.

DOŻAŃSKA E., Homilie w kamieniu, „Miejsca Święte” 2002, nr 2, 29-32.

DYBSKI H., Monastycyzm w Palestynie i Syrii w świetle źródet patrystycznych IV $i V$ wieku, VoxP 22 (2002) t. 42-43, 411-436.

GAJEWSKI W., Obecny stan badań nad organizacja wczesnego Kościoła $w$ świetle pracy „Chrzescijaństwo antyczne” Tadeusza Zielińskiego, „Przegląd Religioznawczy" 2002, nr 205, 39-50.

GILLERT M., Kościót ormiański wyznacznikiem tożsamości narodowej, „Biuletyn Ormiańskiego Towarzystwa Kulturalnego" 2002, nr 30-31, 4-53.

GNILKA J., Piotr i Rzym. Obraz Piotra w pierwszych dwu wiekach, thum. W. Szymona OP, Kraków 2002.

GREGOR P., Dyscyplina pokutna Kościola w pierwszych trzech stuleciach, „Bielsko-Żywieckie Studia Teologiczne” 3 (2002) 389-406.

ILSKI K., Rola i funkcje biskupów nad Dolnym Dunajem, w: Sympozja Kazimierskie [zob. 1], 103-108.

JANIC K., Nestorianie w Chinach, „Mówią Wieki” 2002, nr 10, 8-11.

JANISZEWSKI P., Aniołowie późnego antyku, , ,Mówią Wieki” 2002, nr 1, 611.

JANISZEWSKI P., Czciciele osta, „Mówią Wieki” 2002, nr 6, 6-10.

JANKOWSKI S., Judaizm poświątynny wobec chrześcijaństwa, CT 72 (2002) nr 2, 63-89.

KLUJ W., Pierwsze wspólnoty chrześcijańskie $i$ ich misyjny charakter, CT 72 (2002) $\mathrm{nr}$ 2, 45-62.

KOŚCIELNIAK K., Dwadzieścia wieków chrześcijaństwa $w$ kulturze arabskiej, t. 1. Arabia starożytna, chrześcijaństwo w Arabii do Mahometa (633), Kraków 2000, Wydawnictwo UNUM.

KOWAL F., Elekcja papieza Fabiana (250), w: Ku prawdzie w miłości [1], 33-42. 
KRECIDŁO J., Sq Anglami, niech będq aniołami, „Miejsca Święte” 2002, nr 2, 4-5.

LANGKAMMER H., Niewolnictwo a pierwotny Kościót, „Quaestiones Selectae" 9 (2002) nr 14, 57-71.

LESZKA M.B., Helena, matka Konstantyna Wielkiego, „Mówią Wieki” 2002, nr 4, 30-32.

LESZKA M.J., Aelia Zenonis, żona Bazyliskosa, „Meander” 57 (2002) 87-96.

LESZKA M.J., Konstantyna, żona cesarza Maurycjusza, „Przegląd Nauk Historycznych" 1 (2002) $\mathrm{nr} 1,21-32$.

LESZKA M.J., Śladami Bizantyńczyków po Tesalonice, „Mówią Wieki” 2002, nr 7, 51-57.

LONGOSZ S., Liczba uczestników I Soboru Nicejskiego (325) w realcji Ojców Kościoła IV wieku, w: Ku prawdzie w mitości [1], 71-86.

MADEJSKI D.E., Zbrodnicza „superstitio”. Dzieje konfliktu między państwem rzymskim a chrześcijańskim do pot. IV wieku po Chrystusie, „Zawsze Wierni" 2002, nr 5, 4-22.

MAJEWSKI D., Cesarski więzień. Dziatalność papieża Wigiliusza w Konstantynopolu (547-555), Olsztyn 2002.

MARCINIAK P., Bizantyńskie konkursy piękności, „Mówią Wieki” 2002, nr 8, 6-8.

MILEWSKI I., Biskupi i ich dzieci. Kilka uwag o stanie rodzinnym dostojników kościelnych we wschodnich prowincjach Cesarstwa IV $i \mathrm{~V}$ wieku, w: Dziec$k o w$ rodzinie i społeczeństwie [1], 219-233.

MIOTK A., „Peregrinatio pro Christi amore” we wczesnym średniowieczu, „Studia Warmińskie" 39 (2002) 161-168.

Monastycyzm. Historia i duchowość, pr. zbiorowa, tłum. D. Stadnicka-Apostoł, Kraków - Tyniec 2002.

NAPIÓRKOWSKI C., Ikonoklazm, czyli spór o obrazy, „Miejsca Święte” 2002, nr 8, 22-25.

NAUMOWICZ J., Chrześcijańska rachuba czasu. Refleksje na poczqtek III tysiąclecia (wykład inauguracyjny), „Warszawskie Studia Teologiczne” 15 (2002) 133-140.

PAPROCKI H., Diakonisy (historia i wspótczesność), „Elpis” 4 (2002) 260-272.

PARTYKA J.S., Afryka prowincja Rzymu, „Miejsca Święte” 2002, nr 1, 10-16.

PARTYKA J.S., Arianizm. Religia Wandalów, „Miejsca Swięte” 2002, nr 8, 33 35.

PARTYKA J.S., Kartagina - dziedzictwo Dydony, „Miejsca Święte” 2002, nr 1, 6-9.

PARTYKA J.S., Ostia. Ujście Tybru, „Miejsca Święte” 2002, nr 8, $22-27$.

PARTYKA J.S., Otwarty brzuch Melkarta, „Miejsca Święte” 2002, nr 1, 16-18.

PARTYKA J.S., Poczq̨ek końca rzymskiej Afryki, „Miejsca Święte” 2002, nr $8,17-18$. 
PARTYKA J.S., Zanim urodzit się Augustyn. Poczq̨tki chrześcijaństwa w Afryce Rzymskiej, „Miejsca Święte” 2002, nr 1, 19-21.

PAWLAK M., Niewolnicy prywatni w rzymskiej Afryce w okresie wczesnego Cesarstwa, „Acta Universitatis Wratislaviensis. Historia” 2002, nr 158, $1-147$.

PAWLAK M., Patroklus, biskup Arles w latach 412-426, zaufany człowiek Konstancjusza III, w: Sympozja Kazimierskie [zob. 1], 53-60.

PRZYBYŁ J., Celtyckie chrześcijaństwo - prawda i mistyfikacja, „Rocznik Teologiczny" 44 (2002) nr 2, 53-67.

PRZYGODA W., Znaczenie posługi charytatywnej Kościoła w świetle Ewangelii $i$ świadectwa starożytności chrześcijańskiej, „Studia Sandomierskie” 9 (2002) 185-200.

RAKOCY W., Problem datacji i kolokacji w misji Pawta tzw. Soboru Jerozolimskiego, CT 72 (2002) nr 2, 31-44;

SAWICKI D., Historia Prawostawnego Patriarchatu Bułgarskiego, „Rocznik Teologiczny" 44 (2002) nr 2, 83-105.

STĘPNIEWSKA A., Żeński klub inteligencji chrześcijańskiej na rzymskim Awentynie IV wieku, VoxP 22 (2002) t. 42-43, 261-292.

STĘPOWSKA A., Dziedziczenie beztestamentowe krewnych kognacyjnych $w$ świetle nowel 118 i 127 Justyniana, "Czasopismo Prawno-Historyczne” 54 (2002) nr 1, 57-81.

STOPKA K., Armenia christiana. Unionistyczna polityka Konstantynopola i Rzymu a tożsamość chrzescijaństwa ormiańskiego (IV-XV w.), Kraków 2002, PAU.

STRZELCZYK J., Czarna legenda Wandalów, „Miejsca Swięte” 2002, nr 8, 36-38.

STRZELCZYK J., Pielgrzymowanie do Jerozolimy, „Miejsca Święte” 2002, nr 4, 4-7.

STRZELCZYK J., Wyspa świętych i uczonych, „Miejsca Święte” 2002, nr 2, 6-9. WIPSZYCKA E., De buon uso delle lettere private. Commento a SB III, 7243 E P. Oxy. XIV, 1774, w: Humana sapit. Études d'antiquité tardive offertes à Lellia Cracco Ruggini, ed. J.-M. Carrié et R. Lizzi Testa, Turnhout 2002, 469-473.

WIPSZYCKA E., L'ascétisme féminin dans l'Égypte de l'antiquité tardive: Topoi littéraire et formes d'ascèse, w: Le rôle et le statut de la femme en Égypte hellénistique romaine et byzantine. Actes du Colloque internationale, éd. H. Malaerts et L. Mooren, Leuven 2002, 355-396.

WIPSZYCKA E., L'économie du patriarchat alexandrin à travers les vies de saint Jean l'Aumônier, w: Alexandrie médiévale 2, éd. Ch. Décobert, Paris 2002, 61-81.

WOJCIECHOWSKI M., Ruiny, światynie i pejzaże, „Miejsca Święte” 2002, nr 2, 27-28. 
WÓJCIK M., Świeccy fundatorzy instytucji dobroczynnych w Kościele starożtnym, VoxP 22 (2002) t. 42-43, 327-337.

WOLIŃSKA T., Armeńscy wspótpracownicy Justyniana Wielkiego, cz. 1: Dezerterzy $z$ armii perskiej $w$ Bizancjum, „Przegląd Nauk Historycznych” 1 (2002) $\mathrm{nr}$ 2, 5-31.

WYGRALAK P., Potępienie batwochwalstwa na synodach $w$ Toledo (VI-VII wiek), VoxP 22 (2002) t. 42-43, 475-486.

ZDANOWSKI J., Arabia Wschodnia od czasów najdawniejszych do XII wie$k u$, Warszawa 2002, Wydawnictwo Naukowe ASKON - PAN.

\subsection{Historia doktryn (teologia)}

BAGROWIN J., Inicjacyjno-katechumenalny ksztalt wychowania religijnego, CT 72 (2002) nr 2, 85-108;

BIELECKI S., Chrześcijański kéryks, „Keryks” 1 (2002) 37-51.

BURCZAK K., Biskupi afrykańscy wobec herezji pelagianizmu, VoxP 22 (2002 t. 42-43, 437-461.

CANTALAMESSA R., Pieśń Ducha Świętego. Rozważania na temat Veni Creator, Warszawa 2002, Wydawnictwo Sióstr Loretanek.

CZĘSZ B., „Jesteśmy z jego rodu” (Dz 17, 28): nasza teraźniejszość jako antycypowane doświadczenie przebóstwienia w świetle tradycji patrystycznej, w: Ad sapientiam cordis [1], 27-38.

DANIÉLOU J., Teologia judeochrześcijańska, tłum. S. Basista, Myśl Teologiczna 39, Kraków 2002, Wydawnictwo WAM.

FREGNI G., Miłujcie się czule. Duchowość rodziny wedtug Ojców Kościoła, Kraków 2002, Wydawnictwo ESPE.

GRZESZCZAK J., Sakramentalne skutki inicjacji chrześcijańskiej w ujęciu teologii II wieku, w: Ad sapientiam cordis [1], 81-108.

KACZMAREK T., Symbolika chrzcielna w nauczaniu Kościoła starożytnego, „Studia Włoclawskie” 5 (2002) 137-149.

KALIŃSKI D., Dziewictwo Maryi w tradycji Kościoła Wschodu i Zachodu, „Salvatoris Mater" 4 (2002) $\mathrm{nr}$ 1, 117-134.

KAZIMIERCZAK J., Maryja obrazem Kościoła, „Miejsca Święte” 2002, nr $12,40-42$.

KOCHANIEWICZ B., Dziewictwo Boga - dziewictwo Maryi w ujęciu niektórych Ojców Kościoła, „Salvatoris Mater” 4 (2002) nr 1, 102-116.

KOCZWARA S., Ekumeniczna działalność świeckich dworzan cesarza Justy$n a$ (518-527) $w$ świetle ich korespondencji $z$ Rzymem, VoxP 22 (2002) t. 4243, 319-325.

LONGOSZ S., Geneza i pierwsze znaczenie terminu „świecki” - „laicus” w literaturze wczesnochrześcijańskiej, VoxP 22 (2002) t. 42-43, 53-65.

LONGOSZ S., Ojcowie Kościoła w nauczaniu Jana Pawła II, VoxP 22 (2002) t. $42-43,7-10$. 
LONGOSZ S., Opiekuńcza funkcja Aniołów w nauce Ojców Kościoła (zarys problemu), w: Księga o Aniołach [1], 151-205.

MARCZEWSKI M., Świeccy w Kościolach nowotestamentalnych, VoxP 22 (2002) t. 42-43, 31-51.

MISIARCZYK L., Rola świeckich w pismach Ojców Apostolskich i apologetów greckich II wieku, VoxP 22 (2002) t. 42-43, 67-88.

MISZTAL W., Wiara w pośrednictwo Maryi oraz Jej kult w duchowości pierw. szych chrześcijan, „Salvatoris Mater” 4 (2002) nr 3, 232-251.

NAUMOWICZ J., Chrystus - prawdziwy pedagog, „Pastores” (2002) nr 16, 7 12.

NYK A., Immagine evangelica di Maria Madre di Gesù, VoxP 22 (2002) t. 4243, 391-401.

OZOROWSKI M., Cele matzeństwa w nauczaniu teologów średniowiecza, „Studia Teologiczne Białystok - Drohiczyn - Łomża” 20 (2002) 87-101.

PACZKOWSKI C.M., Chrzest w imię Mojzesza, Jana i Jezusa Chrystusa. Typologia chrzcielna wedtug Bazylego Wielkiego, „Quaestiones Selectae” 9 (2002) nr 14, 83-106.

PAPROCKI H., Dogmat Niepokalanego Poczecia (prawosławny punkt widzenia), ,Elpis" 4 (2002) nr 6, 253-259;

PIESZCZOCH Sz., Patrystyczne podłoże rozwoju wiary $w$ macierzynistwie działania Maryi dla Kościoła i ludzkości, „Studia Gnesnensia” 16 (2002) 105-125.

PIETRAS H., Dwie szkoty mówienia o Jezusie, „List” 1 (2002)21-23.

PIETRAS H., Od prezbiteratu do kaptaństwa: ewolucja pojęć $i$ urzędu, „Studia Bobolanum" 2 (2002) nr 3, 5-17.

PIETRAS H., Pierwotne pojmowanie jedności matżenistwa w Kościele, w: Z.J. Kijas, J. Krzywda (red.), Sakramentalność matzeństwa, Kraków 2002, 9-21, WN PAT.

PIETRAS H., Postrzeganie kaplaństwa, „Znak” 54 (2002) z. 11, 94-104.

PRZYGODA W., Znaczenie postugi charytatywnej Kościoła $w$ świetle Ewangelii $i$ świadectwa starożytności chrześcijańskiej, „Studia Sandomierskie” 9 (2002) 185-200.

ROSIK M., Starożytne przekłady syryjskie „Modlitwy Pańskiej” (Mt 6, 5-15 [9b-13]), „Bielsko-Żywieckie Studia Teologiczne” 3 (2002) 495-502.

RYCHLICKI Cz., Zbawcza konieczność chrztu a wieczny los dzieci nieochrzczonych, „Studia Plockie” 30 (2002) 13-22.

TUREK W., La bastemmia contro lo Spirito Santo (Mt 12,31-32) in san Giovanni Crisostomo, w: M. Maritano (a cura di), Historiam perscrutari. Miscellanea di studi offerti al prof. Ottorino Pasquato (= Biblioteca di Scienze Religiose, 180), Roma 2002, 839-847.

ŻUREK A., Prawo duszpasterzy do „życia z Ewangelii" $w$ świetle tradycji patrystycznej, „Tarnowskie Studia Teologiczne” 21 (2002) 97-117. 


\subsection{Historia doktryn (filozofia)}

KISIEL R., Patrystyczne źródla chrześcijańskiej antropologii filozoficznej, „Legnickie Wiadomości Diecezjalne” 11 (2002) 86-91.

REALE G., Trzy paradygmaty metafizyki stworzone przez myśl greckq $i$ chrześcijańskq, thum. E.I. Zieliński, „Ethos” 15 (2002) nr 59-60, 20-29.

STĘPIEŃ T., Neoplatońska koncepcja emanacji a hierarchiczność spoteczności anielskiej, w: Ksiega o Aniotach, [1], 111-121.

ТОТ И., Бидлейские цитать в «Вердальном поведени» Константина Философа, „Кирило-Методиевски Студии” 14 (2001) 40-44.

ZIELIŃSKI Iwo E., Giovanniego Reale spojrzenie na rozwój myśli filozoficznej starożytności, „Summarium” 30-31 (50-51) (2001-2002) 87-99.

\section{Liturgia}

BARTOSIK G.M., Kult Maryi w liturgii bizantyjskiej, „Seminare” 18 (2002) 67-83.

BLAZA M., Proklamacja Stowa Bożego w bizantyńskiej tradycji liturgicznej, "Studia Bobolanum" 2 (2002) nr 2, 131-155.

BOGUNIOWSKI J.W., Rozwój historyczny ksiąg liturgii rzymskiej do Soboru Florenckiego i ich recepcja w Polsce, Kraków 2001, Wydawnictwo UNUM. Etiopski hymn przed wizerunkiem Maryi, przekład z języka etiopskiego i komentarz R. Zarzeczny, „Przegląd Powszechny” 5 (2002) 153-154.

GINTER K., Spór o Trisagion, „Res Historica” 14 (2002) 221-231.

Hymn koptyjski o Ukrzyżowaniu Pańskim, „Przegląd Powszechny” 7-8 (2002) 11-12.

Hymn św. Pawła z „Męczeństwa św. Pelagii z Cezarei”, zwanego też „Listem św. Pelagii”, tłum. z języka. etiopskiego i komentarz R. Zarzeczny, „Przegląd Powszechny" 9 (2002) 193-194.

Litania do bóstwa Jezusa Chrystusa, tłum. z języka. etiopskiego i komentarz

R. Zarzeczny, „Przegląd Powszechny” 2 (2002) 149-150.

Liturgia koptyjska. Dwudziestu Czterech Starców Apokalipsy, Liturgia koptyjska. Dwudziestu Czterech Starców Apokalipsy, tłum. z języka koptyjskiego i komentarz R. Zarzeczny, „Przegląd Powszechny” 11 (2002) 141-142.

MIAZEK J., Liturgia celtycka, „Miejsca Święte” 2(62) (2002) 25-26.

MIAZEK J., Liturgia celtycka, „Miejsca Święte” 2002, nr 2, 25-26.

Modlitwa niedzielna $z$ IV wieku, thum. z języka greckiego i komentarz R. Zarzeczny, „Przegląd Powszechny” 6 (2002) 305-306.

Modlitwa św. Jana Chrzciciela, tłum. z języka greckiego i komentarz R. Zarzeczny, „Przegląd Powszechny” 1 (2002) 9-10.

PISARZAK M., Nazwy liturgii na Zachodzie, „Liturgia Sacra” 8 (2002) 43-57. POPESCU D., Aspekty dogmatyczne liturgii prawostawnej, thum. H. Paprocki, „Elpis” 4 (2002) nr 6, 111-119.

TSINGOS W., Człowiek i jego odrodzenie według dogmatyki Kościoła prawo- 
sławnego iv aspekcie bizantyjskiej tradycji liturgicznej, thum. J. Pańkowski, „Elpis” 4 (2002) nr 6, 120-143.

\section{Hagiografia i historia duchowości}

BUNGE G., Gliniane naczynia. Praktyka osobistej modlitwy wedkug tradycji świętych Ojców, thum. J. Bednarek - A. Ziernicki, Kraków - Tyniec 2002. Chrystus centrum życia. Wybór tekstów z tradycji monastycznej, Kraków Tyniec 2002, Wydawnictwo Benedyktynów.

DYBSKI H., Monastycyzm w Palestynie i Syrii w świetle źródeł patrystycznych IV $i$ V wieku, VoxP 22 (2002) t. 42-43, 411-436.

FREGNI G., Mitujcie się czule. Duchowość wedtug Ojców Kościoła, Kraków 2002, Wydawnictwo ESPE.

FREJLICH A., Hagiografia bizantyńska jako źródto do dziejów ikony - zagadnienia wybrane, RH 50 (2002) nr 4, 23-35.

JACYNIAK A., Mistyka Wschodu, „Miejsca Swięte” 2002, nr 12, 31-34.

KANIOR M., Historia monastycyzmu chrześcijańskiego, t. 2: Średniowiecze, Kraków 2002, Wydawnictwo UNUM.

KLIMSZA R., Od obrazu do podobieństwa. Osoba ludzka - podmiot duchowości w tradycji chrześcijańskiego Wschodu, „Studia Teologiczne Białystok - Drohiczyn - Łomża" 20 (2002) 267-278.

KOSZNICKI M., Dziecko w tacińskiej hagiografii późnoantycznej, w: Dziecko $w$ rodzinie $i$ spoteczeństwie [1], 234-242.

KRACIK J., Relikwie, Karków 2002.

KRYŚCIAK E., Święta męczennica (Agnieszka), „Espe” 2002, nr 59, s. 74.

MARTYNIUK P., Duchowość Wschodu, „Elpis” 4 (2002) nr 6, 13-24.

MARTYNIUK P., Duchowość Wschodu, „Rocznik Teologii Katolickiej” 1 (2002) 53-63.

Modlitwa Celtów, thum. A. Krajewska, Kraków 2002, Wydawnictwo M.

NAUMOWICZ J., Całun wciąż zagadka, „Księga Swiętych” 1 (2002) 28-29.

NAUMOWICZ J., Czy pokusy sq potrzebne? Sugestie Ojców Kościoła, „Zeszyty Formacji Duchowej" 2002, nr 18, 27-33.

NAUMOWICZ J., Czy potrzebujemy relikwii?, „Biuletyn Katolickiej Agencji Informacyjnej" 9 (518) (3 marca 2002), s. 18-19.

PAJĄK I., Ojcostwo św. Józefa $w$ świetle literatury patrystycznej, „Kaliskie Studia Teologiczne" 1 (2002) 361-367.

PAWLAK L., Brat - mnich, „Via Consecrata” 5 (2002) 28-33.

„Reguła Mistrza” (RMProl - RM 2), tłum. T.M. Dąbek, „Cenobium” 2002 nr 17, 7-31.

RACZKIEWICZ M., Wybór szczęścia według Ojców Kościoła, „Zeszyty Formacji Duchowej" 2002, nr 20, 18-26.

SAWICKI D., Modlitwa Jezusowa i jej wpływ na rozwój duchowości, „Elpis” 4 (2002) nr 6, 39-52; 
SOLIGNAC A. [i inni], Monastycyzm. Historia $i$ duchowość, thum. D. Stanicka-Apostol, Tyniec 2002, Wydawnictwo Benedyktynów.

STAROWIEYSKI M., Męczeństwo świętego Apostota $i$ Ewangelisty Marka w Aleksandrii, w: Ad sapientiam cordis [1], 177-186.

STĘPNIAK W., Św. Katarzyna Aleksandryjska u Stowian Południowych i Zachodnich, „Кирило-Методиевски Студии” 14 (2001) 197-204.

TOFILUK J., Hezychazm i jego wpływ na rozwój duchowości, „Elpis” 4 (2002) nr 6, 87-108;

Wypisy z Filokalii (z ros.) t. 1, red. Paprocki, Warszawa 2002, Warszawska Metropolia Prawosławna.

ZANDER H.C., Święci czyli przedziwne historie Ojców Pustyni, thum. Ks. M. Stebart Cor, Kraków 2002.

\section{Archeologia i historia sztuki}

ABRAMOWICZÓWNA Z., O sztuce starożytnej, przedmowa E. Makowiecka, redakcja tekstu P. Nehring i Z. Nerczuk, Toruń 2002, UAM.

ARNDT M.B., Lampki oliwne typu Jerash z Góry Nebo, „Quaestiones Selectae" 9 (2002) nr 14, 15-21.

BARAŃSKI M., Czy można określić rolę biskupów Hermopolis Magna (Szmun) w ksztaltowaniu miasta?, w: Sympozja Kazimierskie [zob. 1], 237-245.

BULAS R., Bóg i człowiek - wspóttwórcy swiata. Kościót celtycki w Irlandii, „Miejsca Swięte” 2(62) (2002) 12-17.

BULAS R., Symbole pogańskie na celtyckich krzyżach. Mity - symbole obrazy, Lublin 2002, Wydawnictwo KUL.

BUŁGAKOW S., Ikona i kult ikony, thum. H. Paprocki, Bydgoszcz 2002.

CHOMIK P., Ikona w cerkwi prawosławnej, „Cerkiewny Wiestnik” 2002, nr 2, $12-25$.

FREJLICH A., Biskupi i klasztory w Bizancjum w okresie do ustania sporów ikonoklastycznych, w: Sympozja Kazimierskie [zob. 1], 247-253.

FREJLICH A., Hagiografia bizantyńska jako źródto do dziejów ikony - zagadnienia wybrane, RH 50 (2002) nr 4, 23-35.

GAJEWSKA H., Biskupstwo w Tomis i jego rola w ksztattowaniu miast późnoantycznej Scytii Mniejszej, w: Sympozja Kazimierskie [zob. 1], 109-129.

IWASZKIEWICZ-WRONIKOWSKA B., Papieska Komisja Archeologii Sakralnej. Sto pięćdziesiąt lat działalności (1852-2002), VoxP 22 (2002) t. 4243, 515-523.

IWASZKIEWICZ-WRONIKOWSKA B., Rola biskupów jako fundatorów budowli $w$ procesie chrystianizacji Rzymu, w: Sympozja Kazimierskie [zob. 1], 25-41.

IWASZKIEWICZ-WRONIKOWSKA B., Swieccy jako fundatorzy budowli kościelnych w Rzymie wczesnochrześcijańskim, VoxP 22 (2002) t. 42-43, 339-353. 
JAN PAWEŁ II, Przemówienie do uczestników zebrania ogólnego Papieskiej Komisji Archeologii Sakralnej, thum. D. Wronikowska, VoxP 22 (2002) t. $42-43,15-17$.

JAN PAWEŁ II, Starożytne zabytki Kościoła mówiq o wierze pierwszych chrześcijan. Przesłanie z okazji 150. rocznicy powstania Papieskiej Komisji Archeologii Sakralnej (1852-2002), VoxP 22 (2002) t. 42-43, 11-14.

JASTRZĘBOWSKA E., Lokalizacja i datowanie katedry w Efezie, w: Sympozja Kazimierskie [zob. 1], 163-177.

KAŁUŻNY J.C., Biskup Apolinary. Słów kilka o ikonograficznym przestaniu mozaiki z apsydy Bazyliki San Apollinare in Classe, w: Sympozja Kazimierskie [zob. 1], 89-101.

KISS Z., Czy „budowla teatralna” na Kôm El-Dikka (Aleksandria) stużyła do kultu?, w: Sympozja Kazimierskie [zob. 1], 215-223.

KOBIELUS S., Bestiarium chrześcijańskie. Zwierzęta w symbolice i interpretacji. Starożytność $i$ średniowiecze, Warszawa 2002, IW Pax.

KORTE R., Przestanie z podziemi. Przewodnik po katakumbach rzymskich, tłum. B. Fabiani, Warszawa 2002, IW Pax.

MARTENS-CZARNECKA M., Portrety królów nubijskich, w: Sympozja Kazimierskie [zob. 1], 255-277.

MŁYNARCZYK J., Hippos i Diocezarea. Stolice biskupie Palestinae Secundae w źródtach archeologicznych, w: Sympozja Kazimierskie [zob. 1], 193-207.

MYŚLIŃSKI M., Bizantyńskie ikony nadbramne. Kult i funkcja, VoxP 22 (2002) t. 42-43, 501-514.

Obraz $i$ kult. Materiaty z Konferencji „Obraz i kult”, KUL - Lublin, 6-8 października 1999, red. M.U. Mazurczak-J. Patyra, Lublin 2002, Wydawnictwo KUL.

OSTROWSKI J.A., Nike $i$ Wiktoria - ikonograficzne pierwowzory aniotów, w: Księga o Aniołach [1], 473-493.

PARTYKA J.S ., Ostia. Ujścia Tybru, „Miejsca Święte” 8(68) (2002) 22-28.

PARTYKA J.S., Acheropity bizantyjskie, „Miejsca Święte” 2002, nr 4, 16-19.

PARTYKA J.S., Najstarsze wizerunki Jezusa Chrystusa, „Miejsca Święte” 2002, nr 4, 12-15.

PARTYKA J.S., Najstarsze wizerunki Matki Bożej w katakumbach, „Miejsca Święte" 2002, nr 12, 43-45.

PARTYKA J.S., Źródła historyczne i legendy dotyczq̨ce działalności biskupów Hermopolis Magna (Szmun) w kształtowaniu miasta, w: Sympozja Kazimierskie [zob. 1], 225-236.

PAWŁOWSKA B., Sancti tituli w katakumbach rzymskich, „Nowy Filomata” 6 (2002) 57-62.

PIUS XI, Motu proprio „I primitivi cemeteri” o Papieskiej Komisji Archeologii Sakralnej i o nowym Papieskim Instytucie Archeologii Chrześcijańskiej, tłum. E. Kolbus, VoxP 22 (2002) t. 42-43, 19-24. 
PRÓCHNIAK D., Inwestycyjna dziatalność biskupów i katolikosów armeńskich, w: Sympozja Kazimierskie [zob. 1], 131-161.

Regulamin Papieskiej Komisji Archeologii Sakralnej, VoxP 22 (2002) t. 42-43, 25-29.

SKUPIŃSKA-LøVSET I., Miasta bez rzeźb. Konsekwencje zerwania $z$ antyczna tradycja zdobienia miejsc publicznych, w: Sympozja Kazimierskie [zob. 1], 179-192.

STANEK-ŁYSIK M., Lokalizacja zespołów biskupich $w$ miastach wczesnochrześcijańskiej Prowansji, w: Sympozja Kazimierskie [zob. 1], 61-76.

STAWOSKA-JUNDZIŁŁ B., Dzieci $w$ wieku nie przekraczajacym roku w tacińskich inskrypcjach chrześcijańskich z katakumb Rzymu, w: Dziecko $w$ rodzinie i spoteczenistwie [1], 188-204.

STAWOSKA-JUNDZIŁŁ B., Mamma, tata i papas $w$ tacińskich inskrypcjach chrześcijańskich z Rzymu III-VI wieku, VoxP 22 (2002) t. 42-43, 487-500.

\section{Biblia}

BARDSKI K., „Daj mi ustyszeć Twój gtos!”. Wezwanie do zwiastowania Ewangelii w wybranych alegoriach Pieśni nad Pieśniami, „Verbum Vitae” 2002, nr 2, 225-241.

BARDSKI K., Chrystus jako Zbawiciel $w$ alegoryczno-symbolicznej interpretacji epizodu o uciszeniu burzy (Mt 8,23-27; Mk 4,35-5,1; Łk 8,22-26), „Verbum Vitae” 2002, nr 1, 201-226.

MAIER J., Między Starym a Nowym Testamentem. Historia i religia w okresie drugiej Swiątyni, tłum. E. Marszal - J. Zakrzewski, Kraków 2002, Wydawnictwo WAM.

NAUMOWICZ J., Orzech i laska Aarona, czyli zgłębianie i gtoszenie Stowa Bożego w ujęciu Ojców Kościoła, „Verbum Vitae” 2002, nr 2, 243-266.

NIEŚCIOR L., Psalmy $w$ procesie wewnętrznej ewangelizacji chrześcijanina, „Verbum Vitae” 2002, nr 2, 243-251.

ROSIK M., Starożytne przektady syryjskie „Modlitwy Pańskiej” (Mt 6, 5-15 [9b-13]), „Bielsko-Żywieckie Studia Teologiczne” 3 (2002) 495-502.

WOJCIECHOWSKI M., List Pseudo-Arysteasza, SThV 40 (2002) nr 1, 121-167.

\subsection{Apokryfy}

Apokryf Jana, wstęp i thum. W. Myszor (z koptyjskiej wersji NHC II 1), „Sląskie Studia Historyczno-Teologiczne” 35 (2002) 73-89.

Dzieje Swiętego Tomasza Apostoła, thum. i wstęp Luiza Rzymowska, (seria Księgi Osobliwe), Wrocław 2002, Wyd. Uniwersytytu Wrocławskiego.

NAUMOWICZ J., Apokryfy też pożyteczne, „List” 1 (2002) 24-28.

Oda Salomona XI, thum. i komentarz R. Zarzeczny, „Przegląd Powszechny” 10 (2002) 9-10.

OLESCHKO H., Aniotowie w apokryfach Starego i Nowego Testamentu, w: Księga o Aniołach [1], 365-393. 
UCIECHA A., Ideat bezżeństwa , Synów Przymierza” bnay qyāmā w polemice $z$ judaizmem w "Mowach» Afrahata, „Sląskie Studia Historyczno-Teologiczne" 35 (2002) 90-103.

Wizja Adamnana, tłum. J. Sokolski, Wyd. Uniwersytetu Wrocławskiego, Wroclaw 2002 (seria Księgi Osobliwe).

Żywot Adama i Ewy według synaksariów etiopskich, przekład z j. etiopskiego i oprac. Rafał Zarzeczny, „Przegląd Powszechny” 4 (2002), ss. 9-13.

\subsection{Gnostycyzm}

PROKOPIUK J., Istoty anielskie czy demoniczne? Uwagi wstępne $w$ kwestii „istot pośredniczacych” w gnozie i w gnostycyzmie, w: Księga o Aniołach [1], 394-399.

RZYMOWSKA L., Istota gnostycyzmu $w$ świetle interpretacji pojęcia prawdy na przyktadzie wybranych pism apokryficznych, Wroclaw 2002, Wydawnictwo Uniwersytetu Wrocławskiego.

SZMURŁO R., Śmierć Maniego (fragmenty III «Homilii manichejskiej»). Wstęp, komentarz i ttum. z języka koptyjskiego, „Śląskie Studia Historyczno-Teologiczne" 35 (2002) 291-297.

ZMORZANKA A.Z., Kobieta: uczennica $i$ nauczycielka $w$ przekazach gnostyckich, VoxP 22 (2002) t. 42-43, 89-100.

\section{Patrystyka i średniowiecze lacińskie oraz bizantyńskie (źródła i opra- cowania)}

BARTOSIK G.M., Kult Maryi w liturgii bizantyjskiej, „Seminare” 18 (2002) 67-83.

BLAZA M., Proklamacja Stowa Bożego w bizantyńskiej tradycji liturgicznej, „Studia Bobolanum" 2 (2002) nr 2, 131-155.

BRUNO Z KWERFURTU, Żywot pięciu braci męczenników, Tyniec 2002.

BUŁGAKOV S., Ikona i kult ikony. Zarys dogmatyczny, thum. i oprac. H. Paprocki, Bydgoszcz 2002, Wydawnictwo Homini.

CERAN W., Gtówne osiagnięcia polskich badań nad historia sztuki bizantyńskiej (do roku 1998), w: Sztuka średniowiecznego Wschodu i Zachodu. Osiagnięcia i perspektywy poznawcze u progu XXI wieku, red. M. Smorąg Różycka, Kraków 2002, 9-42.

DANTE, Monarchia, Kęty 2002, Wydawnictwo Antyk.

FRANCISZEK i KLARA Z ASYŻU, Pisma. Edycja lacińsko-polska, Kraków 2002, Wydawnictwo $M$.

FREJLICH A., Hagiografia bizantyńska jako źródło do dziejów ikony - zagadnienia wybrane, RH 50 (2002) nr 4, 23-35.

JANISZEWSKI P., Czciciele osta, „Mówią Wieki” 2002, nr 6, 6-10.

JEKEL M., Człowiek średniowiecza wobec ubóstwa, czyli o roli jatmużny $w$ życiu chrześcijanina, „Zeszyty Karmelitańskie” (2002) nr 1, 10-18. 
JUREWICZ O. (red.), Encyklopedia kultury bizantyńskiej, Warszawa 2002, Wydawnictwo Uniwersytetu Warszawskiego.

KOCZWARA S., Ekumeniczna dziatalność świeckich dworzan cesarza Justyna (518-527) w świetle ich korespondencji z Rzymem, VoxP 22 (2002) t. $42-$ $43,319-325$.

LESZKA M.B., Dziewica na bizantyńskim tronie, „Mówią Wieki” 2002, nr 11, 6-11.

LESZKA M.J., Aelia Zenonis, żona Bazyliskosa, „Meander” 57 (2002) 8793.

LESZKA M.J., Konstantyna, żona cesarza Maurycjusza, „Przegląd Nauk Historycznych" 1 (2002) nr 1, 21-32.

LESZKA M.J., Synobójczyni i święta, „Mówią Wieki” 2002, nr 9, 42-46.

LESZKA M.J., Śladami Bizantyńczyków po Tesalonice, „Mówią Wieki” 2002, nr 7, 51-57.

MARCINIAK P., Bizantyńskie konkursy piękności, „Mówią Wieki” 2002, nr 8, 6-8.

MIOTK A., „Peregrinatio pro Christi amore” we wczesnym średniowieczu, "Studia Warmińskie" 39 (2002) 161-168.

MYŚLIŃSKI M., Bizantyńskie ikony nadbramne. Kult i funkcja, VoxP 22 (2002) t. 42-43, 501-514.

OZOROWSKI M., Cele małżeństwa w nauczaniu teologów średniowiecza, „Studia Teologiczne Bialystok - Drohiczyn - Łomża” 20 (2002) 87-101.

PARTYKA J.S., Otwarty brzuch Melkarta, „Miejsca Święte” 2002, nr 1, 1618.

SAWICKA J., Symbolika lunarna w średniowiecznej poezji liturgicznej, „Pamiętnik Literacki" 93 (2002) z. 3, 5-35.

SKRZYNIARZ S., Hades. Recepcja, sens ideowy i przemiany obrazu pogańskiego boga w sztuce bizantyniskiej, seria: Ars Vetus et Nova 7, Kraków 2002, Wydaw. Universitas.

TOMASZ Z AKWINU, Komentarz do Ewangelii św. Jana, Kęty 2002, Wydawnictwo Antyk.

WICKHAM CH., Elity wczesnego średniowiecza, „Mówią Wieki” 2002, nr 11, 6-11.

WOLIŃSKA T., Armeńscy wspótpracownicy Justyniana Wielkiego, cz. 1: Dezerterzy z armii perskiej w Bizancjum, „Przegląd Nauk Historycznych” 1 (2002) nr 2, 5-31.

ZAHAJKIEWICZ M., Średniowieczna teoria misji, „Studia Płockie” 30 (2002) 65-72.

\section{Autorzy}

Afrahat

UCIECHA A., Ascetyczna nauka w „Mowach” Afrahata, Katowice 2002. 
UCIECHA A., Ideat bezżeństwa „synów Przymierza” - bnay qyāmā w polemice $z$ judaizmem $w$ Mowach Afrahata, „Śląskie Studia Historyczno-Teologiczne" 35 (2002) 90-103.

UCIECHA A., Rola i miejsce „synów przymierza” w Kościele perskim IV wieku na przykładzie mów Afrahata, VoxP 22 (2002) t. 42-43, 161-175.

\section{Alkuin}

KIELING M., Terrena non amare sed coelestia. Theologie der Welt in Alkuins Commentaria super Ecclesiasten, Frankfurt a. M. 2002.

KIELING M., , Vanitas” i pragnienie nieba w refleksji teologicznej Alkuina, w: Ad sapientian cordis [1]. 109-124.

KIELING M., Wktad Alkuina w odnowe teologiczna epoki karolińskiej, „Kaliskie Studia Teologiczne" 1 (2002) 161-173.

\section{Ambroży}

GACIA T., „Przyodziej ciala trofeum...”. Soteriologia hymnów św. Ambrożego, ,Verbum Vitae” 2002, nr 1, 227-251.

JAŚKIEWICZ G., Semantyka terminu „morze" w kontekście "Hexaemeronu" św. Ambrożego, „Wiadomości Diecezjalne Siedleckie” 70 (2001) 311-421.

NAKONIECZNY R., Mowa, wymowa i rozmowa $w$ "De officiis» Cycerona $i$ «De officiis ministrorum»św. Ambrożego, „Nowy Filomata” 6 (2002) $109-118$.

NAKONIECZNY R., Zagadnienie mowy $w$ traktatach deontologicznych $C y-$ cerona $i$ św. Ambrożego, „Śląskie Studia Historyczno-Teologiczne” 35 (2002) 271-292.

OBRYCKI K., Św. Ambroży w pracach dyplomowych pisanych na polskich uczelniach katolickich w latach 1945-2000, CT 72 (2002) nr 4, 183-190;

OJCIEC BRUNO, Święta Matka naszego Pana (św. Ambroży), „Zeszyty Maryjne" 5 (2001) nr 3, 15-17.

Perly z Tradycji. Zwierciadto czystości (św. Ambroży - PSP 35), fragmenty wybral A. Langhammer, „Espe” 2002, nr 59, 202-204.

TUREK W., The figure of Paul in the "Lettres" of St. Ambrose, w: T. DrewBear - M. Tashalan (red.), Actes du I Congrès sur Antioche de Pisidie, Paris 2002, 137-146.

TUREK W., Il peccato contro lo Spirito Santo nell' esegesi ambrosiana, „Euntes docete" 54(2001) 71-85.

\section{Ambroży Pseudo-}

-, O godności kapłańskiej (CPL 171A), tłum. Z. Wójtowicz, VoxP 22 (2002) t. $42-43,542-550$.

FIGIEL J., Problem autorstwa i recepcji pisma Pseudo-Ambrożego „O godności kapłańskiej", VoxP 22 (2002) t. 42-43, 537-542.

\section{Atanazy}

CZYŻEWSKI B., Starotestamentalny kanon biblijny św. Atanazego Aleksandryjskiego, w: Ad sapientiam cordis [1], 39-54. 
ŁUKASZEWICZ A., Ostatni ślad Atanazego, w: Sympozja Kazimierskie [zob. 1], 209-213.

Augustyn

-, List św. Augustyna do Fabioli, tłum. J. Pudliszewski, Poznań 2002, Wydawnictwo Naukowe UAM.

-, Pisma monastyczne, wprowadzenie G. Lowless, wstęp i oprac. P. Nehring, thum. P. Nehring, M. Starowieyski, R. Szaszka, ŹM 27, Kraków - Tyniec 2002, Wydawnictwo Benedyktynów.

ECKMANN A., Osobowość dobrego katechety w świetle «De catechizandis rudibus» św. Augustyna, „Keryks” 1 (2002) 53-60.

ECKMANN A., Przebóstwienie człowieka w pismach św. Augustyna. Pojęcia i określenia, „Studia Pelplińskie” 2002, t. 33, 245-264.

FALIŃSKA E., Osobowość dobrego katechety wedtug św. Augustyna na podstawie "De catechizandis rudibus», "Zeszyty Formacji Katechetów" 2 (2002) nr 2, 20-22.

JAŚKIEWICZ S., O roli świeckich w Kościele według św. Augustyna, VoxP 22 (2002) t. 42-43, 223-232.

JUREK I., Umiłowanie mądrości, „Miejsca Święte” 2002, nr 8, 19.

KARPOWICZ A., Teologiczna symbolika śpiewu według „Objaśnień Psalmów" św. Augustyna, 40 (2002) nr 1, 51-78.

KASPRZAK D., Czy św. Augustyn byt filozofem?, „Studia Laurentiana” 2 (2002) nr 1, 7-28.

KUBIAK Z., Pożegnanie w Ostii, „Miejsca Święte” 2002, nr 8, 20-21.

MIOZGA S., Symbolika Babilonu $w$ «De civitate Dei» św. Augustyna, „Nowy Filomata" 6 (2002) 131-144.

NAUMOWICZ J., Doktor taski, „Miejsca Święte” 2002, nr 8, 31-32.

NAUMOWICZ J., Doktor łaski, „Miejsca Święte” 8(68) (2002) 31-32.

OBRYCKI K., Odpowiedź św. Augustyna na memoriat Orozjusza w sprawie btędów pryscylian $i$ orygenistów, „Roczniki Teologiczne Warszawsko-Praskie" 2 (2002) 143-170.

OJCIEC BRUNO, Matka wszystkich wyznawców Chrystusa (św. Augustyn), „Zeszyty Maryjne” 5 (2001) nr 2, 17-20.

OLESCHKO H., Angelologia św. Augustyna: zagadnienia metafizyczne, w: Księga o Aniołach [1], 206-231.

PARTYKA J.S., Syn tylu tez, „Miejsca Swięte” 2002, nr 8, 8-16.

STĘPIEŃ T., Czystość serca a poznanie prawdy. Pseudo-Dionizy Areopagita iśw. Augustyn wobec filozoficznej nauki o czystości, „Warszawskie Studia Teologiczne" 15 (2000) 121-132.

SWOBODA A., Wizerunek matki w pismach Seneki filozofa $i$ w „Enarrationes in Psalmos" św. Augustyna, VoxP 22 (2002) t. 42-43, 233-252.

WNĘTRZAK T., Znaczenie pojęć filozoficzno-politycznych $w$ De Civitate Dei św. Augustyna, Kraków 2002, WN AP. 
WOJEWODA M., Problem wiary i rozumu u Augustyna i Bonawentury na tle filozofii wspótczesnej, „Studia Laurentiana” 2 (2002) nr 1, 29-48.

\section{Bazyli Wielki}

KACZMAREK S., Eklezjalny wymiar pokuty $w$ «Listach» św. Bazylego Wielkiego, „Polonia Sacra” 6 (2002) nr 10, 195-216.

PACZKOWSKI C.M., Chrzest $w$ imię Mojżesza, Jana $i$ Jezusa Chrystusa. Typologia chrzcielna wedtug Bazylego Wielkiego, „Quaestiones Selectae” 9 (2002) nr 14, 83-106.

\section{Benedykt}

DABEK T.M., Rekolekcje ze św. Benedyktem, Kraków 2002, Wydawnictwo M.

DĄBEK T.M., Rozważania wokót "Reguty" św. Benedykta, "Cenobium" 2002, nr 17, 33-40.

ZIOłO M., Jak czytać Regułę (o regule Benedykta), „W Drodze” (2002) nr 11, 69-75.

ZIOŁO M., O milczeniu (w regule Benedykta), „W Drodze” (2002) nr 12, 77 82.

\section{Cezary z Arles}

-, Homilie do Księgi Rodzaju. Objaśnienie Apokalipsy św. Jana, thum., wstęp i oprac. A. Żurek, BOK 17, Kraków 2002, Wydawnictwo M.

GRZYWACZEWSKI J., La lecture à la campagne en Gaule au VI siècle d'après les Sermons de Césaire d'Arles, VoxP 22 (2002) t. 42-43, 463-474.

Perty z Tradycji. Ksiązka czyni duszę wewnętrznie pięknq (św. Cezary z Arles OŻ IV 528-528), fragmenty wybral A. Langhammer, „Espe” 2002, nr 60, 68-69;

Św. Cezary z Arles, wstęp, opracowanie, wybór i przekład A. Żurek, OŻ 17, Kraków: WAM 2002.

ŻUREK A., Wptyw św. Cezarego († 542/3 r.) na życie i ksztatt miasta Arles, w: Sympozja Kazimierskie [zob. 1], 77-87.

\section{Cyprian z Kartaginy}

KRYKOWSKI J., Le nozioni di „conversio” e „conversatio" nell'insegnamento penitenziale di Cipriano di Cartagine, „Studia Loviciensia” 2 (2002) 47-52.

\section{Cyryl Jerozolimski}

JĘDRZEJEWSKA M., Droga inicjacji chrześcijańskiej w Kościele starożytnym na podstawie katechez Cyryla Jerozolimskiego, VoxP 22 (2002) t. 42-43, 403-409.

\section{Dionizy Areopagita Pseudo-}

STĘPIEŃ T., Czystość serca a poznanie prawdy. Pseudo-Dionizy Areopagita i św. Augustyn wobec filozoficznej nauki o czystości, ,Warszawskie Studia Teologiczne" 15 (2000), 121-132.

\section{Efrem}

URBAŃSKI S., „Przez Jezusa do Maryi” w poezji mistycznej św. Efrema, „Częstochowskie Studia Teologiczne” 30 (2002) 195-204. 


\section{Egeria}

MATYSZEWSKI A., Droga inicjacji chrześcijańskiej według "Itinerarium Egeriae», CT 72 (2002) nr 3, 135-154;

\section{Epifaniusz z Salaminy}

-, Pisma przeciw obrazom (CPG 3749-3752), z języka greckiego przełożyła M.M. Dylewska, VoxP 22 (2002) t. 42-43, 557-565.

LONGOSZ S. - DYLEWSKA M.M., Wstęp [do przekładu: Pisma przeciw obrazom], VoxP 22 (2002) t. 42-43, 551-557.

\section{Euzebiusz z Cezarei}

KRÓLIKOWSKI J., Napięcie między świeckościq $i$ sakralnościq $w$ wizji władcy w „De vita Constantini” Euzebiusza z Cezarei, VoxP 22 (2002) t. 42-43, 151160.

\section{Ewagriusz z Pontu}

MISIARCZYK L., Smutek $i$ gniew w nauce duchowej Ewagriusza $z$ Pontu, „Studia Płockie” 30 (2002) 83-96.

NIEŚCIOR L., Czystość serca $i$ umystu wedlug Ewagriusza z Pontu, w: Ad sapientiam cordis [1], 125-150.

NIESCIOR L., Psalmy w procesie wewnętrznej ewangelizacji chrześcijanina. Metoda antyrretyczna Ewagriusza z Pontu, „Verbum Vitae” 2002, nr 2, 243-252.

\section{Filon z Aleksandrii}

-, Kto jest dziedzicem boskich dóbr, tłum., wstęp i przypisy A. Pawlaczyk, Poznań 2002, Wydawnictwo Naukowe UAM, seria: Filologia Klasyczna nr 25.

\section{Fulgencjusz z Ruspe}

KUMALA J., Maryja zrodziła Stwórcę wszechświata (św. Fulgencjusz z Ruspe), ,Zeszyty Maryjne” 5 (2001) nr 6, 14-15.

\section{Grzegorz Palamas}

ROSSUM VAN J., Eucharystia $w$ teologii św. Grzegorza Palamasa, thum. B. Doroszkiewicz, „Elpis” 4 (2002) nr 6, 144-154.

\section{Grzegorz z Nazjanzu}

JAŚKIEWICZ G., Funkcja keryksa w mowach Grzegorza z Nazjanzu, VoxP 22 (2002) t. 42-43, 177-185.

JAŚKIEWICZ G., Życie zakonne w świetle "Mów» Grzegorza z Nazjanzu, „Częstochowskie Studia Teologiczne” 30 (2002) 81-87.

KOMORNICKA A.M., Rady Grzegorza z Nazjanzu dla kaznodziejów, „Meander” 57 (2002) 171-173.

WIDOK N., Postawa Grzegorza z Nazjanzu wobec świeckich $w$ świetle jego listów protekcyjnych, VoxP 22 (2002) t. 42-43, 187-207.

WIDOK N., „Prawo natury” w koncepcji Grzegorza z Nazjanzu, w: Ad plenam unitatem. Księga Pamiq̨tkowa ks. abpa Alfonsa Nosola, red. P. Jaskuła - R. Parada, Opole 2002, 363-372. 


\section{Grzegorz z Nyssy}

STRĘKOWSKI S., Świeccy w ksztattowaniu kultury i duchowości chrześcijańskiej wedtug św. Grzegorza z Nyssy, VoxP 22 (2002) t. 42-43, 209-221.

ZARĘBSKI P., Macierzyński wymiar Kościoła w "Wielkiej Katechezie» św. Grzegorza z Nyssy, „Polonia Sacra” 6 (2002) nr 11, 341-348.

\section{Grzegorz z Tours}

-, Historie. Historia Franków, tłum. K. Liman, T. Richter, wstęp, oprac., komentarz D.A. Sikorski, Kraków - Tyniec 2002, Wydawnictwo Benedyktynów.

DEGÓRSKI B., Postuszeństwo i pokora jako najważniejsze cnoty mnicha $w$ dziełach św. Hieronima, „Dissertationes Paulinorum” 11 (2002) 5-29.

\section{Hieronim}

OJCIEC BRUNO, Obrońca dziewictwa Maryi (św. Hieronim), „Zeszyty Maryjne" 5 (2001) nr 1, 14-15.

PODESZWA P., Typologia Chrystusa cierpiqcego w „Komentarzu do Księgi Jonasza" św. Hieronima, w: Ad sapientiam cordis [1], 151-176.

STĘPNIEWSKA A., Żeński klub inteligencji chrześcijańskiej na rzymskim Awentynie IV wieku, VoxP 22 (2002) t. 42-43, 261-292.

SZCZERBIŃSKI W., Epistolografia konsolacyjna św. Hieronima, w: Ad sapientiam cordis [1], 201-142.

\section{Hilary z Poitiers}

-, Komentarz do Ewangelii św. Mateusza. Traktat o Tajemnicach, PSP 63, thum. E. Stanula, Warszawa 2002.

KOŁOSOWSKI T., Lektura Pisma św. W, duchu" w świetle "Commentarius in Mathaei Evangelium» biskupa Hilarego z Poitiers, „Seminare” 18 (2002) 513-525.

OJCIEC BRUNO, Obrońca Jezusa, prawdziwego Syna Boga i Maryi (św. Hilary), „Zeszyty Maryjne” 5 (2001) nr 4, 15-16.

\section{Hipolit}

NAUMOWICZ J., Kryterium rozróżnienia „duchowny - świecki” wedtug Tradycji Apostolskiej" [Hipolita], VoxP 22 (2002) t. 42-43, 131-140.

\section{Ignacy $z$ Antiochii}

BIELAWSKI K., Niespetniony testament? Uwagi do dziejów relikwii św. Ignacego Męczennika, ,Terminus" 4 (2002) 149-155.

CHADWICK H., Milczenie biskupów u św. Ignacego, thum. K. Bielawski, „Terminus” 4 (2002) 143-148.

\section{Ireneusz z Lyonu}

PIETRAS H., Aniołowie w teologii Ireneusza z Lyonu na tle tradycji judeochrześcijańskiej, w: Księga o Aniołach [1], 131-150.

TUREK W., "Nie ma władzy, która by nie pochodziła od Boga»: Rz 13,1 $w$ interpretacji Ireneusza i Orygenesa, «Studia Plockie» 30 (2002) 55-64.

SZRAM M., Od obrazu do podobieństwa Bożego. Dynamiczna koncepcja 
antropologii teologicznej w II-III wieku (stanowisko Ireneusza i Orygenesa), VoxP 22 (2002) t. 42-43, 357-376.

\section{lzydor z Sewilli}

-, O winorośli (Etymologiae XVII 5), z języka łacińskiego przełożyła, wstępem i komentarzem opatrzyła T. Krynicka, VoxP 42 (2002) t. 42-43, 567-575.

KRYŚCIAK E., Nauczyciel Hiszpanii (św. Izydor z Sewilli), „Espe” 2002, $\mathrm{nr} 60,70$.

\section{Jan Chryzostom}

-, O matzeństwie, wychowaniu dzieci $i$ ascezie, wstęp J. Naumowicz J. Krykowski, tłum. W. Kania, L. Małunowiczówna, K. Bielawski, M. Jurek, J. Rawicka, oprac. J. Naumowicz, BOK 19, Kraków 2002, Wydawnictwo $\mathrm{M}$.

-, Homilia 12 sw. Jana Chryzostoma na List do Kolosan, wprowadzenie i przekład J. Krykowski, „Roczniki Teologiczne Warszawsko-Praskie” 2 (2002) 39-60.

HELLO E., Oblicza świętych. Św. Jan Chryzostom, „Zawsze Wierni” $2002 \mathrm{nr} 1$, 124-134.

TUREK W., La bestemmia contro lo Spirito Santo (Mt 12,31-32) in san Giovanni Crisostomo, w: M. Maritano (a cura di), Historiam perscrutari. Miscellanea di studi offerti al prof. Ottorino Pasquato (= Biblioteca di Scienze Religiose, 180), Las-Roma 2002, s. 839-847.

UCIECHA A., Rola ojca $w$ procesie wychowania domowego na podstawie traktatu św. Jana Chryzostoma „O wychowaniu dzieci”, w: Dziecko w rodzinie i spoteczeństwie [1], 205-218.

\section{Jan Damasceński}

DYLEWSKA M., Koncepcja świętych wizerunków u św. Jana Damasceńskiego, „Memoranda” 76 (2002) 672-678.

\section{Jan Kasjan}

-, Rozmowa z Ojcami, t. 1, tłum., A. Nocoń, ŹM 28, Tyniec - Kraków 2002, Wydawnictwo Benedyktynów.

\section{Jan z Berytu}

-, Homilia paschalna, tłum. i komentarz Rafał Zarzeczny, „Przegląd Powszechny" 3 (2002) 287-289.

\section{Justyn}

LÓPEZ GARCA M.M., La autobiografía de san Justino en el "Dialogo con Trifón" $2-8,2$ y elementos autobiográficos de Taciano en el "Discurso contra los Griegos» 29, 35, 41, „Warszawskie Studia Teologiczne” 15 (2002) 101-120.

\section{Kasjodor}

KRAWCZYK A., Rola książki we «Wskazaniach dotyczących czytania (dziet) Boskich» Flawiusza Aureliusza Kasjodora, „Res Historica” 13 (2002) 3985. 


\section{Klemens Rzymski}

SIEŃKOWSKI M., Elementy duchowości chrześcijańskiej w Liście do Kościola w Koryncie św. Klemensa Rzymskiego, „Ełckie Studia Teologiczne” 3 (2002) 89-105.

\section{Klemens Aleksandryjski}

DRĄCZKOWSKI F., Jezus Chrystus Zbawiciel w pismach Klemensa Aleksandryjskiego, w: Ku prawdzie w mitości [1], 43-62.

DRACZKOWSKI F., Powszechność funkcji keryksa w Kościele starożytnym. Stanowisko Klemensa Aleksandryjskiego, VoxP 22 (2002) t. 42-43, 101117.

DRĄCZKOWSKI F., Rodzaje świadczenia Chrystusowi w nauce Klemensa Aleksandryjskiego, „Studia Pelplińskie” 2002, t. 33, 209-218.

Perty z Tradycji. Szczęśliwszy, kto ubóstwem się podpiera (Klemens Aleksandryjski - OŻ III 204-205), fragmenty wybral A. Langhammer, „Espe” 2002, nr 58, 78-79.

SWOBODA A., Ideał męża w pismach Epikteta i Klemensa Aleksandryjskiego, AK 138 (2002) z. 558, 319-332.

SWOBODA A., Ideat ojca $w$ pismach Epikteta i Klemensa Aleksandryjskiego, w: Ad sapientiam cordis [1], 187-200.

SZCZUR P., Oblicza mitości. Cnoty pokrewne $i$ towarzyszqce agape według Klemensa Aleksandryjskiego, Lublin 2002.

SZCZUR P., Urząd biskupa w świetle pism Klemensa Aleksandryjskiego, w: Ku prawdzie w mitości [1], 63-70.

\section{Kolumban Starszy}

SAREŁO Z., Śladami św. Kolumby, „Miejsca Święte” 2002, nr 2, 49-52.

\section{Leander z Sewilli}

WYGRALAK P., Zachęta do dziewictwa $w$ "De institutione virginum et de contemptu mundi" św. Leandra $z$ Sewilli, w: Ad sapientiam cordis [1], 243-251.

\section{Leon Wielki}

KUMALA J., Maryja - Matka Chrystusa, prawdziwego Boga i prawdziwego człowieka (św. Leon Wielki), „Zeszyty Maryjne” 5 (2001) nr 5, 16-18.

ŻUREK A., Laikat rzymski w świetle mów Leona Wielkiego, VoxP 22 (2002) t. 42-43, 293-301.

\section{Maksym z Turynu}

DRAZZZEK D., Dwa kazania św. Maksyma z Turynu o św. Wawrzyńcu na tle starożytnej tradycji o tym rzymskim męczenniku, „Studia Pelplińskie” 2002, t. 33, 219-227.

\section{Minucjusz Feliks}

Perty z Tradycji. Szczesśliwszy, kto ubóstwem się podpiera (Minucjusz Feliks OŻ II 370-371), fragmenty wybrał A. Langhammer, „Espe” 2002, nr 58, 7879. 


\section{Nowacjan}

-, O widowiskach, tłum. członków Kola Naukowego studentów filologii klasycznej Uniw. Wrocławskiego pod kier. J. Pigonia, „Meander” 57 (2002) 69-76. EDER M., Traktat Nowacjana „O widowiskach” - kilka uwag o tekście i autorze, „Meander” 57 (2002) 59-68.

KWACZEK A., „De spectaculis” Nowacjana - kompozycja, wzorce, odniesienia, „Meander” 57 (2002) 77-86.

\section{Orozjusz}

OBRYCKI K., Odpowiedź św. Augustyna na memoriat Orozjusza w sprawie błędów pryscylian i orygenistów, „Roczniki Teologiczne Warszawsko-Praskie" 2 (2002) 143-170.

\section{Orygenes}

-, Komentarz do Ewangelii wedlug św. Mateusza, cz. II. Commentariorum series, thum. K. Augustyniak, ŹMT 25, Kraków 2002, Wydawnictwo WAM.

GEADYSZEWSKI L., Proroctwo Symeona o mieczu w interpretacji Orygenesa, w: Ad sapientiam cordis [1], 55-80.

SZRAM M., Od obrazu do podobieństwa Bożego. Dynamiczna koncepcja antropologii teologicznej w II-III wieku (stanowisko Ireneusza i Orygenesa), VoxP 22 (2002) t. 42-43, 357-376.

SZRAM M., Udziat wiernych świeckich $w$ funkcjach wspótcześnie zastrzeżonych kaptanom urzędowym oraz $w$ strukturach instytucjonalnych Kościota w ujęciu Orygenesa, VoxP 22 (2002) t. 42-43, 141-149.

TUREK W., "Nie ma wtadzy, która by nie pochodziła od Boga»: Rz 13,1 $w$ interpretacji Ireneusza i Orygenesa, «Studia Płockie» 30 (2002) 55-64.

\section{Patryk}

NAUMOWICZ J., Święty Patryk - Apostot Zielonej Wyspy, „Miejsca Święte” 2002, nr 2, 18-21.

\section{Paulin z Noli}

KASPRZAK D., Il pensiero sociale di Paolino da Nola, „Studia Laurentiana” 2, Suplement 1 (2002) 7-236 (ss. 229-233: Myśl socjalna św. Paulina z Nolistreszczenie).

PAŁUCKI J., Jezus jako Zbawiciel w nauczaniu Paulina $z$ Noli, „Verbum Vitae" 2002, nr 1, 253-269.

PAŁUCKI J., Świeccy adresaci listów Paulina z Noli, VoxP 22 (2002) t. 42-43, 253-260.

PAŁUCKI J., Teologiczna interpretacja dziatalności budowlanej św. Paulina z Noli, w: Sympozja Kazimierskie [1], 43-51.

PAŁUCKI J., Teologiczna interpretacja dziatalności budowlanej św. Paulina z Noli, w: Ku prawdzie w miłości [1], 87-94.

\section{Possydiusz z Kalamy}

-, Żywot św. Augustyna, wstęp, tłum. i oprac. P. Nehring, ŹM 26, Tyniec 2002, Wydawnictwo Benedyktynów. 


\section{Pseudo-Dionizy Areopagita}

DZIELSKA M., Porzqdek anielski $w$ Hierarchii niebiańskiej Pseudo-Dionizego Areopagity, w: Księga o Aniołach, [1], 122-130.

STĘPIEŃ T., Czystość serca a poznanie prawdy. Pseudo-Dionizy Areopagita $i$ św. Augustyn wobec filozoficznej nauki o czystości, „Warszawskie Studia Teologiczne" 15 (2002) 121-132.

\section{Tacjan Syryjezyk}

LÓPEZ GARCA M.M., La autobiografía de san Justino en el «Dialogo con Trifón» $2-8,2$ y elementos autobiográficos de Taciano en el "Discurso contra los Griegos» 29, 35, 41, „Warszawskie Studia Teologiczne” 15 (2002) 101-120.

\section{Tertulian}

KOŁOSOWSKI T., , Ubi tres, Ecclesia est, licet laici”. Duchowieństwo a laikat we wspólnocie kartaginiskiej według Tertuliana, VoxP 22 (2002) t. 42-43, 119-130.

NAUMOWICZ J., Jak stawać się chrześcijaninem. Aforyzmy Tertuliana, „Miejsca Święte” 2002, nr 1, 22-23.

STAWINOGA R., Tertulian a świat antyczny, Kraków 2002, Wydawnictwo Zakonu Pijarów, ss. 207.

STRĘKOWSKI S., Godność ciała w polemice Tertuliana przeciwko poglqdom filozofów greckich na podstawie „De resurrectione mortuorum”, VoxP 22 (2002) t. 42-43, 377-390.

\section{Recenzje, omówienia}

BARTOSZEWICZ D. (rec.), M. Szram, Duchowy sens licz $b$ w alegorycznej egzegezie aleksandryjskiej (II-IV w.) - „Warszawskie Studia Teologiczne” 15 (2002) 255-256.

BRALEWSKI S., Duchowni na bizantyńskim dworze (rec. książki: M.B. Leszka, Rola duchowieństwa na dworze cesarzy wczesnobizantyńskich, Łódź 2000) - „Przegląd Nauk Historycznych" 1 (2002) nr 1, 188-192.

BUBEL G. (rec.), Dokumenty Soborów Powszechnych, t. 1, tekst grecki, łaciński, polski, red. A. Baron - H. Pietras, Kraków 2001, Wydawnictwo WAM - „Studia Bobolanum” 2002, nr 3, 156-158.

BUBEL G. (rec.), K. Schatz, Sobory Powszechne. Punkty zwrotne w historii Kościoła, thum. J. Zakrzewski, Kraków 2001, Wydawnictwo WAM „Studia Bobolanum” 2002, nr 3, 159-163.

BURCZAK K. (rec.), H.G. Reichert, Unvergängliche lateinische Spruchweisheit: urban und human, Erzabtei St. Ottilien 1997 - VoxP 22 (2002) t. 42-43, 624-628.

CICHOCKI G. (rec.), G.M. Bartosik, Przez Ciebie jaśnieje radość. Kult Maryi w liturgiach Wschodu i Zachodu, Niepokalanów 1999, Wyd. Franciszkanów - AK 138 (2002) z. 558, 426-427. 
DZIUBA A.F. (rec.), J.Z. Lachowicz, La mujer en la vida y el pensamiento de San Gregorio Magno (540-604), Pamplona 2000 - VoxP 22 (2002) t. 42-43, 610-615.

FIGIEL J. (rec.), Dokumenty Soborów Powszechnych. Tekst grecki, laciński, polski, uklad i opracowanie ks. A. Baron - ks. H. Pietras SJ, t. 1: (325-787) Nicea I-Konstantynopol I-Efez - Chalcedon -Konstantynopol II - Nicea II, Kraków 2001; t. 2: (869-1312) Konstantynopol IV - Lateran I - Lateran II - Lateran III - Lateran IV - Lyon I - Lyon II - Vienne, Kraków 2002 VoxP 22 (2002) t. 42-43, 621-623.

GŁADCZUK Cz. (rec.), W. Jaeger, Paideia - formowanie czlowieka greckiego, Warszawa 2001, Fundacja Aletheia, „Studia Teologiczne Białystok Drohiczyn - Łomża" 20 (2002) 511-514.

GÓRSKI G. (rec.), Starożytne kodyfikacje prawa. Materiaty z konferencji zorganizowanej 10-11 kwietnia 1999 roku w Lublinie, Lublin 2000, RW KUL "Czasopismo Prawno-Historyczne" 54 (2002) nr 1, 443-444.

GROŃ R. (rec.), J. Leclercq, Chrystus w oczach średniowiecznych mnichów, thum. M. Borkowska, Kraków - Tyniec 2001, Wydaw. Benedyktynów „Życie Konsekrowane” 2002, nr 5, 102-103.

KARAŚ A. (rec.), Sw. Tomasz czyta Boecjusza (rec. książki S. Bafii, Komentarz św. Tomasza $z$ Akwinu do «De hebdomadibus» $i$ «De Trinitate» Boecjusza, Kraków 1999, Wydawnictwo Naukowe PAT) - „Logos i Ethos” 2001, nr 1, 152-154.

KASIŁOWSKI P. (rec.), J. Gnilka, Die frühen Christen. Ursprünge und Angang der Kirche. Herders Theologischer Kommentar zur Neuen Testament, Supplementband VII, Freiburg - Basel - Wien 1999 - „Studia Bobolanum" 2 (2002) $\mathrm{nr}$ 1, 169-174.

KRYKOWSKI J. (rec.), R. Selejdak, Diakonat staty w świetle Biblii $i$ historii Kościoła, Częstochowa 2002, Biblioteka „Niedzieli” - „Studia Lovicensia” 4 (2002) 283-284.

LESZKA M.J. (rec.), A.A. Kluczek, Polityka dynastyczna w Cesarstwie Rzymskim w latach 235-284, Katowice 2000, Wydaw. Uniwersytetu Śląskiego „Przegląd Nauk Historycznych" 1 (2002) nr 1, 192-196.

LONGOSZ S. (rec.), J. Daniélou, Teologia judeochrześcijańska. Historia doktryn chrześcijaniskich przed Soborem Nicejskim, tłum. ks. S. Basista, Kraków 2002 - VoxP 22 (2002) t. 42-43, 577-581.

MALINA A.M. (rec.), I. Salamonowicz-Górska, Język taciński dla teologów, Katowice 2001, Księgarnia św. Jacka - „Śląskie Studia Historyczno-Teologiczne" 35 (2002) 460-461.

MARCZEWSKI M. (rec.), M. Daniluk, Encyklopedia instytutów życia konsekrowanego i stowarzyszeń życia apostolskiego. Pojęcia - terminy - instytucje - dokumenty - czasopisma, Lublin 2000, RW KUL - „Homo Dei” 72 (2002) 165-166. 
MISIARCZYK L. (rec.), D. Rokéah, Justin Martyr and the Jews, Leiden Boston -Köln 2002 - VoxP 22 (2002) t. 42-43, 584-587.

MISIARCZYK L. (rec.), J. Lieu, Image and reality. the Jews in the world of the Christians in the second Century, Edinburgh 1996 - VoxP 22 (2002) t. 42-43, 581-584.

MISIARCZYK L. (rec.), T.J. Horner, „Listening to Trypho”. Justin Martyr's Dialogue Reconsidered, Leuven 2001 - VoxP 22 (2002) t. 42-43, 588-592.

MYSZOR W. (rec.), J. Naumowicz, Geneza chrześcijańskiej rachuby lat. Historyczno-teologiczne podstawy systemu Dionizego Mniejszego, Kraków Tyniec 2000, Wydawnictwo Benedyktynów - „Sląskie Studia HistorycznoTeologiczne" 35 (2002) nr 1, 167-169.

MYSZOR W. (rec.), J. Słomka, Pokarm i ofiara. Refleksja eucharystyczna wczesnych Ojców greckich, Łódź 2000, Archidiecezjalne Wydawnictwo Łódzkie - „Śląskie Studia Historyczno-Teologiczne” 35 (2002) nr 1, 169 172.

MYSZOR W. (rec.), T. Kołosowski, Od wolności wyboru wyznania do przymusu religijnego. Ewolucja poglądów biskupa Augustyna z Hippony podczas schizmy donatystycznej w Afryce Rzymskiej, Piła 2000 - „Śląskie Studia Historyczno-Teologiczne" 35 (2002) 164-166.

PIETRAS H. (rec.) - Dokumenty Soborów Powszechnych. Tekst grecki, taciński, polski, t. 1 (325-787), Kraków 2001, WAM - „Życie Duchowe” 2002, nr 31, 169-170.

PIETRAS L.T. (rec.), Bazil Velký, Listy II. Hexaémeron, preložil, úvodnú štúdiu a vysvetlivky napísal a registre zostavil Daniel Škoviera, Prešov 2002 - VoxP 22 (2002) t. 42-43, 601-602.

PYKA M. (rec.), Sw. Augustyn, Pisma o małzeństwie i dziewictwie, przekład i komentarz zbiorowy, red. i wprowadzenie ks. A. Eckmann, Lublin 2003 VoxP 22 (2002) t. 42-43, 605-608.

SŁOTWIŃSKA H: (rec.), F. Drączkowski, Metoda wykresograficzna w katechezie, Pelplin 2001, Bernardinum - „Katecheta” 46 (2002) nr 7-8, 134-136.

STOKŁOSA K. (rec.), M. Borkowska, Twarze Ojców pustyni, Kraków 2001 „Życie Duchowe” 2002, nr 29, 171-173.

SUSKI R. (rec.), Dary papirusów (rec. książki A. Łukaszewicza, Świat papirusów, Warszawa 2001, Książka i Wiedza) - „Mówią Wieki” 2002, nr 7, 61.

SUSKI R. (rec.), Krzyż $i$ starzy bogowie (rec. książki D. Musial, Antyczne korzenie chrześcijaństwa, Warszawa 2001, Wydawnictwo Trio) - „Mówią Wieki" 2002, nr 4, 56.

SUSKI R. (rec.), Wakacje z Quo Vadis (rec. książki E. Jastrzębowskiej, Rzym w czasach „Quo Vadis”, Warszawa 2001, Prószyński i S-ka) - „Mówią Wieki" 2002, nr 2, 60-61.

SZRAM M. (rec.), D. Hombergen, The Second Origenist Controversy. A New Perspective on Cyril of Scythopolis' Monastic Biographies as Historical 
Sources for Sixth-Century Origenism, Roma 2001 - VoxP 22 (2002) t. 42-43, 592-599.

WOJTCZAK-SZYSZKOWSKI J. (rec.), M. Szram, Duchowy sens liczb $w$ alegorycznej egzegezie aleksandryjskiej (II-V w.), Lublin 2001 - VoxP 22 (2002) t. 42-43, 599-601.

WOJTCZAK-SZYSZKOWSKI J. (rec.), N. Widok, Physis w pismach Grzegorza z Nazjanzu. Studium z teologii patrystycznej, Opole 2001 - VoxP 22 (2002) t. 42-43, 602-605.

WOŹNIAK J (rec.), S. Weninger, Das Verbalsystem des Altäthiopischen. Eine Untersuchung seiner Verwendung und Funktion unter Berücksichtigung des Interferenzproblems, Wiesbaden 2001 - VoxP 22 (2002) t. 42-43, 628-629.

WOŹNIAK J. (rec.), J. Tropper, Altäthiopisch. Grammatik des Ge'ez mit Übungstexten und Glossar, Münster 2002 - VoxP 22 (2002) t. 42-43, 629-630. WOŹNIAK J. (rec.), S. Weninger, Ge'ez. Classical Ethiopic, München - Newcastle 1993 - VoxP 22 (2002) t. 42-43, 630.

WYSOCKI M. (rec.), B. Daley, The Hope of the Early Church, A handbook of patristic Eschatology, Peabody Mass. 2003 - VoxP 22 (2002) t. 42-43, 615621.

ZBROJA B. (rec.), Apocalisse di Giovanni con commento tratto dai Padri, Santi e Mistici della Chiesa, red. A. Barzaghi, Montespertoli 1997 - „Polonia Sacra" 6 (2002) nr 11, 401-402.

ŻUREK A. (rec.), A. Fürst, Hieronymus. Askese und Wissenschaft in der Spätantike, Freiburg in Breisgau 2003 - VoxP 22 (2002) t. 42-43, 609-610.

\section{Sprawozdania}

DEGÓRSKI B., „Wyznania” św. Augustyna (402-2002). Podsumowanie i widoki na przyszłość (XXXI Dni Augustiańskie, Rzym, 2-4 V 2002), VoxP 22 (2002) t. 42-43, 764-767.

DEGÓRSKI B., Klasyczne tematy chrześcijańskiej tradycji monastycznej (50lecie Instytutu Monastycznego „Anselmianum”, Rzym 28 V - 1 VI 2002), VoxP 22 (2002) t. 42-43, 767-771.

DRACZKOWSKI F., Sw. Augustyn odkrywany przez muzutmanów (Alger Annaba - Souk-Ahras, 1-7 IV 2001), VoxP 22 (2002) t. 42-43, 772-776.

KOTKOWSKA E., ,Jeden chrzest na odpuszczenie grzechów” (Sekcja Patrystyczna, Kielce, 23-24 IX 2002), VoxP 22 (2002) t. 42-43, 757-760.

LACHOWICZ J., Świeccy w Kościele starożytnym (Lublin, KUL, 25-26 XI 2002), VoxP 22 (2002) t. 42-43, 741-750.

ROSIK M., 40 Sympozjum Biblistów Polskich nt. „Naród żydowski i jego Święte Pisma w Biblii chrześcijańskiej" (Metropolitalne WSD w Lublinie 19-20 IX 2002) - „Życie Konsekrowane” 2002, nr 6, s. 110-112.

SZMURŁO R., Chrześcijaństwo II-V wieku wobec antycznych tradycji ezoterycznych Warszawa, UKSW, 16 X 2002), VoxP 22 (2002) t. 42-43, 760-764. 
WRÓBLEWSKI P., Chrześcijaństwo w pluralistycznym świecie Cesarstwa Rzymskiego II-V wieku. Sprawozdanie z sympozjum patrystycznego, CT 72 (2002) nr 4, 190-191.

ZMORZANKA A.Z., Posiedzenia Komisji Badań nad Antykiem Chrześcijańskim KUL w roku akademickim 2002/2003, VoxP 22 (2002) t. 42-43, 751756.

\section{Wybrane publikacje z zakresu kultury klasycznej}

a) Przeklady

AMMIANUS MARCELLINUS, Dzieje rzymskie, t. 2, księgi XXVI-XXXI, seria: Biblioteka Antyczna, tłum., wstęp i przypisy I. Lewandowski, Warszawa 2002, Prószyński i S-ka.

ANDOKIDES, Mowy, Biblioteka Przekladów z Literatury Starożytnej 13, Kraków 2002, PAU.

APEL W., Kleakai a androu. Zarys dziejów greckiej poezji epickiej od Choirilosa do Nonnosa, Toruń 2002, Wydawnictwo UMK.

APULEJUSZ Z MADAURY, O Bogu Sokratesa $i$ inne pisma, Warszawa 2002, Wydawnictwo Naukowe PWN.

FILODEMOS, O muzyce, o utworach poetyckich, epigramy, Biblioteka antyczna, Warszawa 2002, Prószyński i S-ka

HERODOT, Dzieje, tłum. i oprac. S. Hammer, Warszawa: „Czytelnik” 2002.

KLAUDIANUS KLAUDIUSZ, $O$ drugim konsulacie Stylichona. $O$ wojnie $z$ Gotami, Wydawnictwo Ling-Pi, Warszawa 2002.

KUBIAK Z., Grecy o miłości, szczęściu i życiu. Epigramaty z Antologii Palatyńskiej, Warszawa 2002, Grupa Wydawnicza Bertelsmann Media.

KUPIS B., Fragmenty Presokratyków. Ksenofanes, „Meander” 57 (2002) nr 1, 37-44.

KUPIS B., Presokratycy. Epicharm, „Meander” 57 (2002) nr 2, 155-164.

KWINTYLIAN Marek Fabiusz, Ksztatcenie mówcy, ks. I, II i X, thum. Warszawa 2002, Wydawnictwo Akademickie Żak.

OWIDIUSZ, Żale (wybór), Poznań 2002, Wydawnictwo Ars nova.

PROKLOS, Elementy teologii, tłum. R. Sawa, wstęp i redakcja naukowa M. Dzielska, Warszawa 2002, Wydawnictwo „Akme”.

TEOFRAST, Przyczyny powstawania i rozwoju roślin. Fizjologia roślin, thum. i oprac. H. Wójtowicz, Lublin 2002, TN KUL.

\section{b) Opracowania}

BOSOWSKI A., Cezarea prokuratorów od Augusta do Nerona, Warszawa 2002. DODDS E.R., Grecy i racjonalność, tłum. J. Partyka, Bydgoszcz 2002, Wydawnictwo Homini.

GRENIER A., Historia Galów, Gdańsk - Warszawa 2002, Wydawnictwo Marabut i Oficyna Wydawnicza Volumen. 
JAŻDŻEWSKA K., O pochodzeniu „Fizjologa”, „Warszawskie Studia Teologiczne" 15 (2002) 85-100.

KISIEL E.M., Małe dziecko $w$ rodzinie $w$ percepcji pedagoga i moralisty Plutarcha $z$ Cheronei, w: Dziecko w rodzinie i spoteczeństwie [1], 175-187.

KOKOSZKO M., Elementy fizjonomiki w Deipnosofistach Atenajosa z Naukratis, ,Meander” 57 (2002) nr 2, 125-140.

KOWALSKI H., Pietas jako wyznacznik odniesień między rodzicami a dziećmi w republikańskim Rzymie, w: Dziecko w rodzinie i spoteczeństwie [1], 8696.

KROKIEWICZ A. Sceptycyzm grecki. Od Pirrona od Karneadesa, Warszawa 2002, Wydawnictwo Aletheia.

NICZYPORUK P., Żałoba i powtórne matżeństwo w prawie rzymskim, Biatystok 2002, Wyd. Temida.

RUDNICKA W., Dziecko w szkole elementarnej za czasów Cesarstwa Rzymskiego, w: Dziecko w rodzinie i spoteczeństwie [1], 143-154.

SŁUŻEWSKA Z., Prawo rzymskie w internecie, „Zeszyty Prawnicze” 2 (2002) nr 1, 141-158.

SZARMACH M., Pismo Plutarcha «De audiendo» $i$ jego problematyka, „Meander” 57 (2002) nr 2, 165-170.

ZIELIŃSKI T., Hellenizm a judaizm, Toruń 2002, Wydawnictwo Adam Marszałek.

opracowali

ks. Józef Naumowicz - Warszawa, UKSW ks. Stanisław Longosz - Lublin, KUL 